\title{
Glycemic index and glycemic load of arrowroot (Maranta arundinaceae) cookies with the addition of cinnamon (Cinnamomum verum) and porang (Amorphophallus oncophyllus) glucomannan
}

\author{
${ }^{1,2,3}$ Lestari, L.A., ${ }^{1}$ Gama, D.B., ${ }^{1,2}$ Huriyati, E., ${ }^{4}$ Prameswari, A.A. and ${ }^{5 *}$ Harmayani, E. \\ ${ }^{1}$ Department of Nutrition and Health, Faculty of Medicine, Public Health and Nursing, Universitas Gadjah \\ Mada, Jalan Farmako, Sekip Utara, Yogyakarta, Indonesia 55281 \\ ${ }^{2}$ Center for Health and Human Nutrition, Faculty of Medicine, Public Health and Nursing, Universitas \\ Gadjah Mada, Jalan Farmako, Sekip Utara, Yogyakarta, Indonesia 55281 \\ ${ }^{3}$ Institute for Halal Industry and System, Universitas Gadjah Mada, Jalan Kaliurang KM 4, Yogyakarta, \\ Indonesia 55281 \\ ${ }^{4}$ Graduate Programme of Public Health, Faculty of Medicine, Public Health and Nursing, Universitas \\ Gadjah Mada, Jalan Farmako, Sekip Utara, Yogyakarta, Indonesia 55281 \\ ${ }^{5}$ Department of Food and Agricultural Product Technology, Faculty of Agricultural Technology, \\ Universitas Gadjah Mada, Jalan Flora No. 1, Bulaksumur, Yogyakarta, Indonesia 55281
}

Article history:

Received: 28 November 2019

Received in revised form: 31

January 2020

Accepted: 3 February 2020

Available Online: 19

February 2020

Keywords:

Functional food,

Glycemic index,

Glycemic load,

Arrowroot,

Glucomannan,

Cinnamon

DOI:

https://doi.org/10.26656/fr.2017.4(3).401

\begin{abstract}
Development of functional food especially diabetic food has recently increased since the prevalence of type 2 diabetes mellitus has increased dramatically. Hence, we developed My Cookies ${ }^{\circledR}$ that made from several ingredients that could lower the blood glucose namely arrowroot (Maranta Arundinaceae), cinnamon (Cinnamomum verum), and porang (Amorphophallus oncophyllus) glucomannan. The objective of this study was to evaluate the nutrient composition, glycemic index, and glycemic load of My Cookies ${ }^{\circledR}$. Cookie samples were analyzed for their nutrient composition using proximate analysis methods. The total sugar and total starch of cookies were analyzed with colorimetric method and enzymatic method, respectively, while dietary fiber and resistant starch were analyzed with enzymatic-gravimetric method. The glycemic index and glycemic load were determined using Wolever and Jenkins method. The result showed that the cookies contain water, ash, protein, fat, total carbohydrate, soluble fiber, insoluble fiber, and resistant starch as much as $7.20 \%, 2.66 \%, 7.66 \%, 28.00 \%, 54.49 \%, 0.57 \%, 15.80 \%$ and $2.23 \%$ respectively. Glycemic index and glycemic load of the cookies were 48.2 and 6.92 respectively. Since the glycemic index and glycemic load were categorized as low, it can be concluded that My Cookies ${ }^{\circledR}$ could be consumed by diabetics as an alternative snack.
\end{abstract}

\section{Introduction}

There are many functional foods that have beneficial health effect, one of which is lowering the blood glucose level. Functional foods are foods that have specific health effects because they contain certain bioactive compounds (Iwatani and Yamamoto, 2019). Indonesia has adopted the definition of functional foods according to FOSHU, Japan. National Agency for Drug and Food Control of Indonesia (NADFC) have issued some regulation regarding functional food and food with a specific health claim, includes food for controlling blood glucose level.

Development of functional food for diabetics is very important in Indonesia due to the increase of diabetes mellitus (DM) in Indonesia. According to the Basic Health Research Survey conducted by the Indonesian Ministry of Health in 2018, the proportion of people with $\mathrm{DM}$ is $2.0 \%$. However, in a certain city like Yogyakarta, the proportion exceeds the national average i.e. $2.3 \%$ (Indonesian Ministry of Health, 2018). According to International Diabetes Federation (IDF), there were 382 million people living with diabetes in the world in 2013 and by 2035 the number is expected to increase to 592 million (Indonesian Ministry of Health, 2014). The American Diabetes Association (2011) stated that approximately $90-95 \%$ of the worldwide incidence of diabetes is Type 2 Diabetes Mellitus (T2DM). T2DM requires good blood glucose control to prevent complications. 
Controlling diet is the most important thing in T2DM therapy. Diet contain high dietary fiber and resistant starch can help control blood sugar and complications in DM (Post et al., 2012). Soluble dietary fiber can prolong gastric emptying and decrease macronutrient absorption so that it can reduce postprandial glucose levels. According to Den Besten et al. (2013), dietary fiber can be fermented by colonic flora and produced short-chain fatty acids, subsequently, it will reduce the level of fatty acids and increasing insulin sensitivity. Snack for diabetics is commercially sold in Indonesia, however, the consumer's acceptance is considered low since the taste is not acceptable and expensive.

My Cookies ${ }^{\circledR}$ were made from arrowroot, cinnamon, and porang glucomannan for the diabetics. Each ingredient has lowering blood glucose properties. Arrowroot tubers flour contain $14.86 \%$ of total dietary fiber (Harmayani et al., 2011). Since the dietary fiber is high in arrowroot and the glycemic index is low, hence arrowroot can be developed as a snack for diabetics (Marsono, 2002). Lestari et al. (2017) developed cookie bar from three main ingredients namely foxtail millet, arrowroot flour, and kidney beans. It was found that the glycemic index of the cookie bar was 37.6, hence it can be categorized as low GI foods. The cinnamon extract contains antioxidant compounds that can control glycemic response (Sahib, 2016). Another research conducted by Yulia et al. (2015) found that cinnamon extract could reduce blood glucose levels in rats fed high fructose diet. According to Jakhetia et al. (2010), cinnamon contains bioactive components such as cinnamaldehyde, cinnamic acid, cinnamide, and essential oil that could give health benefits. Glucomannan is a polysaccharide from the mannan group consisting of $\beta$ $1,4 \alpha$-mannose and $\alpha$-glucose monomers. Porang tubers (Amorphophallus oncophyllus) contains glucomannan that has properties of reducing blood glucose and cholesterol levels in (Kumar et al., 2013).

The aims of this research were to evaluate the nutrient composition, glycemic index, and glycemic load of My Cookies ${ }^{\circledR}$ as well as its potency as a functional snack for diabetics.

\section{Materials and methods}

\subsection{Materials}

Arrowroot flour (Kusuka, Bantul, Indonesia) and arrowroot starch (Mekarsari, Kulonprogo, Indonesia) were purchased from a local home industry in Yogyakarta Special Province of Indonesia. Glucomannan was extracted from porang (Amorphophallus oncophyllus) tubers in our laboratory. The porang tubers were obtained from Nglanggeran, Gunungkidul, Yogyakarta Special Province of Indonesia. Cinnamon powder (Koepoe Koepoe, Jakarta, Indonesia), cornstarch (Honig Maizenaku, Jakarta, Indonesia), palm sugar (Gula Semut Jogja, Kulonprogo, Indonesia), cane sugar (Rose Brand, Jakarta, Indonesia), margarine (Forviita, Bekasi, Indonesia), skim milk (NZMP, New Zealand), salt (Refina, Gresik, Indonesia), baking powder (Koepoe Koepoe, Jakarta, Indonesia), vanilla extract (Koepoe Koepoe, Jakarta, Indonesia) and whole egg was purchased from local supermarket and bakery ingredients shop.

\subsection{My Cookies ${ }^{\circledR}$ formulation}

Margarine and sugar (6.0\% cane sugar and 6.5\% palm sugar) were mixed with mixer for 5 mins, then the whole egg was added and mixed with mixer for 3 mins. Skim milk, arrowroot flour, arrowroot starch, and other ingredients were added gradually until mixed thoroughly. The dough was rolled and flattened before cutting into a round shape. The cutout dough was baked at $140^{\circ} \mathrm{C}$ for 25 mins in the oven. After baking, the cookies were cooled to room temperature and put into a plastic container. The sugar contents of My Cookies ${ }^{\circledR}$ was lower than the cookies formula from Peter Ikechukwu et al. (2017) who added cane sugar as much as $14.15 \%$ ( $60 \mathrm{~g}$ in $424 \mathrm{~g}$ dough).

\subsection{Nutrient analysis}

Water, ash, crude protein, and crude fat was analyzed with the methods of AOAC (2012), whereas total carbohydrate was calculated by difference. The energy of My Cookies ${ }^{\circledR}$ was calculated by multiplying the percentage of protein and carbohydrate with 4 and crude fat with 9. Total sugar was determined using the Nelson-Somogyi methods (AOAC, 2012). Total starch was determined using enzymatic colorimetry methods (AOAC, 2012). Soluble and in-soluble fiber were determined using enzymatic-gravimetric methods by Asp et al. (1983), while resistant starches were analyzed using the method by Goni et al. (1996).

\subsection{Glycemic Index (GI) determination}

As many as ten volunteers aged 18-23 years with a body mass index (BMI) between 18.5 and $22.9 \mathrm{~kg} / \mathrm{m}^{2}$, having normal fasting blood glucose $(70-110 \mathrm{mg} / \mathrm{dL})$, and have good-health condition, participated in the GI determination. The volunteers who had a history of diabetes and/or other metabolic syndromes as well as pregnant or breastfeeding during blood glucose sampling were excluded from the study.

The subjects were assigned for fasting for 8-10 hrs before the GI test. They arrived at the clinical laboratory 
in the morning. After filling out the informed consent form, they were explained about the rules and procedure during the GI test. Firstly, their fasting capillary blood glucose level was determined. Subsequently, they had to consume the test meal (glucose as a reference or My Cookies ${ }^{\circledR}$ as test food) within 10 mins. Anhydrous glucose (Sigma-Aldrich) was used as a reference and given by dissolving $25 \mathrm{~g}$ in $150 \mathrm{~mL}$ of water and consumed within 10 mins. The test food was tested 1 week after. The subjects had to consume as much as 36.8 $\mathrm{g}$ of My Cookies ${ }^{\circledR}$ within 10 mins. The food reference and test food had $25 \mathrm{~g}$ of available carbohydrate. After 30 mins from they finished to eat test food, the capillary blood glucose level was determined, and then it was determined again at 60, 90, and 120 mins. Blood glucose responses after glucose or My Cookies ${ }^{\circledR}$ consumption were then calculated for the glycemic index. The area under the blood responses curve was calculated with the formula from Wolever and Jenkins (1986) as follow:

$\mathrm{L}=\frac{\Delta 30 t}{2}+\Delta 30 t+\frac{(\Delta 60-\Delta 30) t}{2}+\Delta 60 t+\frac{(\Delta 90-\Delta 60) t}{2}+\Delta 90 t+\frac{(\Delta 120-\Delta 90) t}{2}$

Where, $L$, the area under the curve; $t$, time interval blood sampling; D30, the difference in blood glucose level 30 min after the load with fasting; D60, the difference in blood glucose level 60 mins after the load with fasting; D90, the difference in blood glucose level 90 mins after the load with fasting; D120, the difference in blood glucose levels 120 mins after the load with fasting.

\section{Results and discussion}

3.1 Nutrient composition of My Cookies ${ }^{\circledR}$ and Its contribution to the dietary requirements of diabetics

The development of My Cookies ${ }^{\circledR}$ was intended to give more choices for diabetics to consume snack with a low glycemic index. Table 1 shows that My Cookies ${ }^{\circledR}$ contained macronutrients that contributed to the dietary requirements of diabetics. Although the amount of fat and sugar were high, however the amount of dietary fiber also high. Dietary fiber could inhibit the digestion and absorption of sugar as well as fat in the gastrointestinal tract (Capuano, 2017). According to the Indonesian Association for Endocrinologist Consensus (2015), there are several methods to calculate the calorie requirement, one of them is calculating the basal calorie needs of 25 $30 \mathrm{kcal} /$ body weight. The proportion of macronutrients intake is $10-20 \%$ protein, $20-25 \%$ fat, and $45-65 \%$ carbohydrates. American Association of Clinical Endocrinologists (AACE) guidelines stated that patients with type 2 diabetes need a 1,500 to $1,800 \mathrm{kcal}$ per day in order to reduce and/or maintain ideal body weight. The need for energy may vary depending on age, sex, level of physical activity, and body weight (Garvey et al., 2016).

Consuming 2-3 pieces of My Cookies ${ }^{\circledR}$ contribute $9.18 \%$ of energy, $2.81 \%$ of protein, $23.10 \%$ of fat, and $6.66 \%$ of carbohydrates if it is assumed that diabetics need 1,800 kcal per day. The fat content of My

Table 1. Nutrient composition of arrowroot cookies per $100 \mathrm{~g}$ and per serving $(33 \mathrm{~g})$

\begin{tabular}{lcccc}
\hline \multicolumn{1}{c}{ Nutrient } & Unit & Content per 100 g & Content per serving & $\begin{array}{c}\text { Contribution to the } \\
\text { Dietary Requirements }\end{array}$ \\
\hline Energy & $\mathrm{kcal}$ & $500.56 \pm 0.26$ & $165.18 \pm 0.09$ & $9.18 \%$ \\
Water & $\mathrm{g}$ & $7.20 \pm 0.02$ & $2.37 \pm 0.01$ & $0.88 \pm 0.01$ \\
Ash & $\mathrm{g}$ & $2.66 \pm 0.04$ & $2.53 \pm 0.02$ & $2.81 \%$ \\
Protein & $\mathrm{g}$ & $7.66 \pm 0.07$ & $9.24 \pm 0.01$ & $23.10 \%$ \\
Fat & $\mathrm{g}$ & $28.00 \pm 0.04$ & $17.98 \pm 0.03$ & $6.66 \%$ \\
Total Carbohydrate by difference & $\mathrm{g}$ & $54.49 \pm 0.08$ & $14.04 \pm 0.10$ & $7.61 \pm 0.10$ \\
Total sugar ${ }^{2)}$ & $\mathrm{g}$ & $42.56 \pm 0.31$ & $0.19 \pm 0.00$ & $2.60 \%$ \\
Starch & $\mathrm{g}$ & $23.05 \pm 0.31$ & $5.21 \pm 0.03$ & $5.40 \pm 0.03$ \\
Soluble fiber & $\mathrm{g}$ & $0.57 \pm 0.01$ & $0.73 \pm 0.00$ & \\
Insoluble fiber & $\mathrm{g}$ & $15.80 \pm 0.09$ & $16.37 \pm 0.10$ & \\
Total dietary fiber ${ }^{3)}$ & $\mathrm{g}$ & $\mathrm{g}$ & $2.23 \pm 0.01$ & \\
Resistant starch & $\mathrm{g}$ & & \\
\hline
\end{tabular}

${ }^{1)}$ According to the Indonesian Association for Endocrinologist (2015), protein requirement for a diabetic is 10-20\% of total energy; fat requirement is $20-25 \%$, and carbohydrate requirement is $45-65 \%$. It is assumed that the energy requirement is 1,800 $\mathrm{kcal}$ (for male with bodyweight of $60 \mathrm{~kg}$ ) and contribution to dietary requirements were calculated based on 1,800 kcal; protein $20 \%$; fat $20 \%$; and carbohydrate $60 \%$. My Cookies ${ }^{\circledR}$ contributes $9.18 \%$ of calories needed in each time consumption, hence it can be consumed 3 times a day to fulfill the calories needed.

${ }^{2)}$ For a diabetic person, there are limitation of sugar (sucrose) consumption i.e. $5 \%$ from total energy or approximately $22.5 \mathrm{~g}$ per day if it assumed that calorie intake is $1,800 \mathrm{kcal}$. Analysis of total sugar consists of several monosaccharide and disaccharide, hence the contribution to the dietary requirements of sucrose could not be calculated.

${ }^{3)}$ Dietary fiber requirement for diabetics is $20-35 \mathrm{gr} /$ day. 
Cookies ${ }^{\circledR}$ is high since it contributed $23.10 \%$ of the recommendation from the Indonesian Association for Endocrinologist Consensus (2015), even more so the sugar content was also high. On the other hand, My Cookies ${ }^{\circledR}$ contained a high amount of dietary fiber and resistant starch. Hence, the glycemic index of My Cookies ${ }^{\circledR}$ is needed to determine.

\subsection{Glycemic Index and glycemic load}

The glycemic index (GI) is a value of the effect of the consumption of certain food on 2 hrs postprandial blood glucose response with respect to an equivalent carbohydrate portion of references namely bread or glucose. GI provides a ranking on a scale from 0 to 100 , where foods with GI of $\geq 70$ are classified as high GI, 56 -69 as moderate GI, and $\leq 55$ as low GI (Huang and Miskelly, 2017). GI can be calculated from the incremental area under the blood glucose response curve for a $50 \mathrm{~g}$ available carbohydrate portion of a test food stated as a percentage of the response to the same amount of carbohydrate from standard food taken by the same subject. However, in this study, we used a $25 \mathrm{~g}$ carbohydrate portion to decrease the amount of My Cookies ${ }^{\circledR}$ that had to be consumed. A total of 13 subjects were screened for this study, 3 of them were withdrawn due to not be able to collect capillary blood sampling. Health status of the subjects, 7 females and 3 males, were examined by a physician and all of them were met with the inclusion criteria. The average of subjects' body mass index (BMI) was $20.57 \pm 0.97 \mathrm{~kg} / \mathrm{m}^{2}$ and fasting blood glucose was $80.75 \pm 1.74 \mathrm{mg} / \mathrm{dL}$.

The amount of My Cookies ${ }^{\circledR}$ that had to be consumed was calculated based on its total sugar and total starch content that equal to $25 \mathrm{~g}$ carbohydrate in food reference, hence the subjects had to consume $36.8 \mathrm{~g}$ cookies within 10 mins. Figure 1 showed that blood glucose responses after ingestion of anhydrous glucose were higher than My Cookies ${ }^{\circledR}$. The area of the glucose curve was 3540, whereas the area of My Cookies ${ }^{\circledR}$ curve was 1707 , hence the GI of My Cookies ${ }^{\circledR}$ was 48.2. My Cookies ${ }^{\circledR}$ can be classified as low GI food since the GI value is below 55. Our previous study with different arrowroot cookies formula $(9.3 \%$ of cane sugar or $9.3 \%$ of palm sugar) showed that arrowroot cookies have GI as much as 25.6 and 19.6 respectively. It was found that arrowroot cookies with palm sugar give a lower GI value than with cane sugar (Gama et al., 2019).

The GI value of certain food depends on the amount and composition of carbohydrates as well as the fat and protein content of the food, acidity, particle size, cooking methods (Eleazu, 2016). Different components of carbohydrates could affect glycemic responses. Monoand disaccharides such as glucose, fructose, galactose, sucrose as well as digestible starches are digested rapidly so that the glucose absorption is fast (Lestari et al., 2017). On the contrary, non-digestible starch such as resistant starch, non-digestible oligosaccharide, and dietary fiber are not digested thus the glycemic response are low.

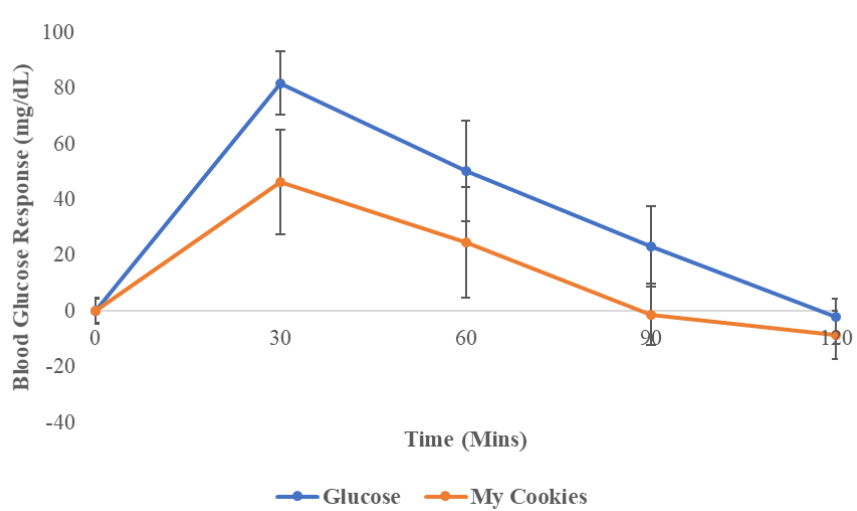

Figure 1. Blood glucose response after ingestion of test meal

Glycemic load (GL) was defined as the glycemic response to a consumed food which depends on the total amount of carbohydrates consumed. GL calculates for how much of carbohydrate is in the food and how each gram of carbohydrate in the food increases blood glucose levels. GL is categorized as low $(<10)$, intermediate $(11-$ 19), and high (>20) (Barclay et al., 2008; Campbell, 2011). Table 2 showed that My Cookies ${ }^{\circledR}$ has GL as much as 6.92, hence it can be categorized as low GL food. Our previous study found that arrowroot cookies with $9.3 \%$ of cane sugar have GL of 17.6 while arrowroot cookies with $9.3 \%$ of palm sugar have GL of 13.7. It was found that arrowroot cookies with palm sugar give a lower GL value than with cane sugar (Gama et al., 2019). GL is a metric used to control weight loss or diabetes, hence food with high glycemic load could result in an increased risk of diabetes and obesity (Das et al., 2007).

Table 2. GI and GL calculation of My Cookies ${ }^{\circledR}$

\begin{tabular}{cccc}
\hline Parameter & Value & $\begin{array}{c}\text { Interpretation of GI } \\
\text { or GL }\end{array}$ & Reference \\
\hline GI & 48.2 & Low & $\begin{array}{c}\text { Huang and Miskelly } \\
(2017)\end{array}$ \\
GL & 6.92 & Low & $\begin{array}{c}\text { Campbell (2011); } \\
\text { Barclay et al. (2008) }\end{array}$ \\
\hline
\end{tabular}

Note: GL calculation was based on the amount of available carbohydrates per serving size (14.35 g carbohydrates per $33 \mathrm{~g}$ My Cookies $($ )).

Decreasing of the glycemic index of a food can be achieved by decreasing the glycemic index and/or by eliminating most of the carbohydrates from the food (Jenkins et al., 2011). Different types of carbohydrates resulted in different blood glucose response. My 
Cookies ${ }^{\circledR}$ was made from arrowroot starches and flour. Arrowroot (Maranta arundinaceae L.) is tuber crop originated from Indonesia. It is believed that arrowroots could soothe upset stomachs hence it is used for some food product ingredient such as cookies, porridge, etc. The arrowroot flour contains $11.9 \%$ water, $0.58 \%$ ash, $25.9 \%$ amylose, $0.14 \%$ protein, $0.84 \%$ fat, $8.7 \%$ insoluble dietary fiber, and $5.0 \%$ soluble dietary fiber (Kumalasari et al., 2012). Arrowroot flour is a potential source of prebiotics (Harmayani et al., 2011). On the other hand, boiled arrowroot tuber has a low glycemic index as little as 14 (Marsono, 2001). Based on these characteristics, arrowroot is the most suitable carbohydrate source for diabetic foods. My Cookies ${ }^{\circledR}$ was added with glucomannan, a soluble dietary fiber, from porang tubers. Glucomannan has several health benefits such as reduce the levels of blood glucose, cholesterol, triglycerides, blood pressure, and body weight (Devaraj et al., 2018).

Another ingredient in My Cookies ${ }^{\circledR}$ that have blood glucose lowering effect is cinnamon. Cinnamon is known to have anti-diabetic properties (Bahmachari et al., 2009; Aggarwal, 2010). Subash Babu et al. (2007) investigated hypoglycaemic effect of cinnamaldehyde extract in streptozotocin-induced diabetic rats. It was found that the plasma glucose and HbAlc level were decreased. Medagama (2015) conducted a systematic review concerning the clinical trial of cinnamon powder on the level of blood glucose and HbAlc in diabetics. The dosage of cinnamon powder was ranging from 500 $\mathrm{mg}$ to $6 \mathrm{~g}$ per day for a duration lasting from 40 days to 4 months. Fasting blood glucose and $\mathrm{HbA1c}$ levels were decreased after the administration of cinnamon powder.

In respect of the low GI and GL value of My Cookies ${ }^{\circledR}$ and ingredients' characteristic as glycemic control agents, hence this cookie can be consumed as an alternative snack for diabetics. My Cookies ${ }^{\circledR}$ is expected to control the level of blood glucose and $\mathrm{HbA} 1 \mathrm{c}$ levels among diabetics.

\section{Conclusion}

Consuming one serving size (33 gram) of arrowroot cookies My Cookies ${ }^{\circledR}$ provides $9.18 \%$ of energy, $2.81 \%$ of protein, $23.10 \%$ of fat, and $6.66 \%$ of carbohydrate needed by diabetics. My Cookies ${ }^{\circledR}$ have GI and GL value as little as 48.2 and 6.92 respectively, hence it can be consumed by diabetics as a snack food and have potency in controlling blood glucose level. A further clinical trial using type 2 diabetics patients is needed to prove the glycemic control of My Cookies ${ }^{\circledR}$.

\section{Conflict of Interest}

The authors declare no conflict of interest.

\section{Acknowledgments}

The research work was funded by Directorate of Research, Universitas Gadjah Mada (UGM) through the Rekognisi Tugas Akhir (RTA) grant (3151/UN1/DITLIT/ DIT-LIT/LT/2019) granted to Dr Lily Arsanti Lestari.

\section{References}

Aggarwal, B.B. (2010). Targeting inflammation-induced obesity and metabolic diseases by curcumin and other nutraceuticals. Annual Review of Nutrition, 30, 173-199. https://doi.org/10.1146/ annurev.nutr.012809.104755

American Diabetes Association (2011). Diagnosis and classification of diabetes mellitus. Diabetes Care, 34 (Supplement 1), S62-S69. https://doi.org/10.2337/ dc11-S062

AOAC. (2012). AOAC Official Methods of Analysis, 18th ed. Gaithersburg, USA: AOAC International.

Asp, N.G., Johansson, C.G., Halmer, H. and Siljestrom, M. (1983). Rapid enzymatic assay of insoluble and soluble dietary fiber. Journal of Agricultural Food Chemistry, 31, 476-482. https://doi.org/10.1021/ jf00117a003

Bahmachari, S., Jana, A. and Pahan, K. (2009). Sodium benzoate, a metabolite of cinnamon and a food additive, reduces microglial and astroglial inflammatory responses. The Journal of Immunology, 183(9), 5917-5927. https:// doi.org/10.4049/jimmunol.0803336

Barclay, A.W., Petocz, P., McMillan-Price, J., Flood, V.M., Prvan, T., Mitchell, P. and Brand-Miller, J.C. (2008). Glycemic index, glycemic load, and chronic disease risk - a meta-analysis of observational studies. American Journal of Clinical Nutrition, 87 (3), 627-637. https://doi.org/10.1093/ajcn/87.3.627

Campbell, B. (2011). Glycemic Load vs Glycemic Index. Retrieved on October 13, 2019 from NSAC website: www.nsac-lift.org

Capuano, E. (2017). The behavior of dietary fiber in the gastrointestinal tract determines its physiological effect. Critical Reviews in Food Science and Nutrition, 57(16), 3543-3564. https:// doi.org/10.1080/10408398.2016.1180501

Das S.K., Gilhooly, C.H., Golden, J.K., Pittas, A.G., Fuss, P.J., Cheatham, R.A., Tyler, S., Tsay, M., McCrory, M.A., Lichtenstein, A.H., Dallal, G.E., Dutta, C., Bhapkar, M.V., Delany, J.P., Salyzman, E. and Roberts, S.B. (2007). Long-term effects of 2 
energy-restricted diets differing in glycemic load on dietary adherence, body composition, and metabolism in CALERIE: a 1-y randomized controlled trial. American Journal of Clinical Nutrition, 85(4), 1023-1030. https://doi.org/10.1093/ ajcn/85.4.1023

Den Besten, G., van Eunen, K., Groen, A.K., Venema, K., Reijngoud, D.J. and Bakker, B.M. (2013). The role of short-chain fatty acids in the interplay between diet, gut microbiota, and host energy metabolism. Journal of Lipid Research, 54(9), 23252340. https://doi.org/10.1194/jlr.R036012

Devaraj, R.D., Reddy, C.K. and Xu, B. (2019). Healthpromoting effects of konjac glucomannan and its practical applications: A critical review. International Journal of Biological Macromolecules, 126, 273-281. https://doi.org/10.1016/ j.ijbiomac.2018.12.203

Eleazu, C.O. (2016). The concept of low glycemic index and glycemic load foods as panacea for type 2 diabetes mellitus; prospects, challenges and solutions. African Health Science, 16(2), 468-479. https://doi.org/10.4314/ahs.v16i2.15

Gama, D.B., Harmayani, E. dan Lestari, L.A. (2019). Perbandingan Uji Sifat Kimia, Indeks Glikemik (IG), dan Beban Glikemik (BG) Antara Kukis Garut (Maranta arundinaceae) yang Mengandung Glukomanan Porang (Amorphophalus oncophyllus) dengan Penambahan Gula Aren dan Gula Tebu. Yogyakarta, Indonesia: Universitas Gadjah Mada, BSc. Thesis. [In Bahasa Indonesia].

Garvey, T.W., Mechanick, J.I., Brett, E.M., Garber, A.J., Hurley, D.L., Jastreboff, A.M., Nadolsky, K., Pessah -Pollack, R., Plodkowski, R. and Reviewers of the AACE/ACE Obesity Clinical Practice Guidelines. (2016). American Association of Clinical Endocrinologists and American College of Endocrinology Comprehensive Clinical Practice Guidelines for Medical Care of Patients with Obesity. Endocrine Practice, 22(Suppl. 3), 1-203. https://doi.org/10.4158/EP161365.GL

Goni, I., Garcia-Diz, L., Manas, E. and Saura-Calixto, F. (1996). Analysis of resistant starch: a method for foods and food products. Food Chemistry, 56(4), 445 -449. https://doi.org/10.1016/0308-8146(95)00222-7

Harmayani, E., Kumalasari, I.D. and Marsono, Y. (2011). Effect of arrowroot (Marantha arundinaceae L.) diet on the selected bacterial population and chemical properties of caecal digesta of Sprague Dawley rats. International Research Journal of Microbiology, 2(8), 278-284.

Huang, S. and Miskelly, D. (2017). Steamed Bread: Ingredients, Process, and Quality. USA: Elsevier
Ltd.

Indonesian Ministry of Health (2018). Basic Health Research Survey. Retrieved on November 25, 2018 from website: https://www.depkes.go.id/resources/ download/info-terkini/materi_rakorpop_2018/ Hasil\%20Riskesdas\%202018.pdf

Indonesian Ministry of Health (2014). Situasi dan analisis Diabetes. Retrieved on November 25, 2018 from website: https://www.depkes.go.id/resources/ download/pusdatin/infodatin/infodatin-diabetes.pdf

Indonesian Association for Endocrinologist Consensus (Perkeni). (2015). Konsensus Pengelolaan dan Pencegahan Diabetes Melitus Tipe 2 di Indonesia. Retrieved on October 13, 2019 from Perkeni website: https://pbperkeni.or.id/wp-content/ uploads/2019/01/4.-Konsensus-Pengelolaan-danPencegahan-Diabetes-melitus-tipe-2-di-IndonesiaPERKENI-2015.pdf

Iwatani, S. and Yamamoto, N. (2019). Functional food products in Japan: A review. Food Science and Human Wellness, 8(2), 96-101. https:// doi.org/10.1016/j.fshw.2019.03.011

Jakhetia, V., Patel, R., Khatri, P., Pahuja, N., Garg, S., Pandey, A. and Sharma, S. (2010). Cinnamon: A Pharmacological review. Journal of Advanced Scientific Research, 1(2), 19-23.

Jenkins, D.J., Srichaikul, K., Kendall, C.W., Sievenpiper, J.L., Abdulnour, S., Murrahimi, A., Meneses, C., Nishi, S., He, X., Lee, S., So, Y.T., Esfahani, A., Mitchell, S., Parker, T.L., Vidgen, E., Josse, R.G. and Leiter, L.A. (2011). The relation of low glycaemic index fruit consumption to glycaemic control and risk factors for coronary heart disease in type 2 diabetes. Diabetologia, 54(2), 271-279. https://doi.org/10.1007/s00125-010-1927-1

Kumalasari, I.D., Harmayani, E., Lestari, L.A., Raharjo, S., Asmara, W., Nishi, K. and Sugahara, T. (2012). Evaluation of immunostimulatory effect of the arrowroot (Maranta arundinacea $\mathrm{L}$ ) in vitro and in vivo. Cytotechnology, 64(2), 131-137. https:// doi.org/10.1007/s10616-011-9403-4

Kumar, P., Lokesh, T., Gobinath, M., Kumar, B. and Saravanan, D. (2013). Anti-diabetic and antihyperlipidemic Activities of Glucomannan Isolated from Araucaria cunninghamii seeds. Journal of Chemical and Pharmaceutical Sciences, 6(3), 204208

Lestari, L.A., Huriyati, E. and Marsono, Y. (2017). The development of low glycemic index cookie bars from foxtail millet (Setaria italica), arrowroot (Maranta arundinacea) flour, and kidney beans (Phaseolus vulgaris). Journal of Food Science and 
Technology, 54(6), 1406-1413. https:// doi.org/10.1007/s13197-017-2552-5

Marsono, Y. (2001). Glycemic index of selected Indonesian starchy foods. Indonesian Food and Nutrition Progress, 8, 15-20.

Marsono, Y. (2002). Indeks Glisemik Kacang-kacangan. Jurnal Teknologi dan Industri Pangan, 13, 211-216.

Medagama, A.B. (2015). The glycaemic outcomes of Cinnamon, a review of the experimental evidence and clinical trials. Nutrition Journal, 14, 108. https:// doi.org/10.1186/s12937-015-0098-9

Peter Ikechukwu, A., Okafor, D.C., Kabuo, N.O., Ibeabuchi, J.C., Odimegwu, E.N., Alagbaoso, S.O., Njideka, N.E. and Mbah, R.N. (2017). Production and Evaluation of Cookies from Whole Wheat and Date Palm Fruit Pulp as Sugar Substitute. International Journal of Advancement in Engineering Technology, Management and Applied Science (IJAETMAS), 4(4), 1-31.

Post, R.E., Mainous, A.G., King, D.E. and Simpson, K.N. (2012). Dietary Fiber for the Treatment of type 2 Diabetes Mellitus: A Meta-Analysis. The Journal of the American Board of Family Medicine, 25(1), 16-23. https://doi.org/10.3122/jabfm.2012.01.110148

Sahib, A.S. (2016). Anti-diabetic and antioxidant effect of cinnamon in poorly controlled type- 2 diabetic Iraqi patients: A randomized, placebo-controlled clinical trial. Journal of Intercultural Ethnopharmacology, 5(2), 108-113. https:// doi.org/10.5455/jice.20160217044511

Subash Babu, P., Prabuseenivasan, S. and Ignacimuthu, S. (2007). Cinnamaldehyde-A Potential Antidiabetic Agent. Phytomedicine, 14(1), 15-22. https://doi.org/10.1016/j.phymed.2006.11.005

Wolever, T.M. and Jenkins, D.J. (1986). The use of the glycaemic index in predicting the blood glucose response to mixed meals. American Journal of Clinical Nutrition, 43(1), 167-172. https:// doi.org/10.1093/ajen/43.1.167

Yulia, A., Suparmo and Harmayani, E. (2015). Pengaruh Minuman dari Ekstrak Kayu Manis-Madu terhadap Kadar Gula Darah tikus terinduksi Aloksan. Jurnal penelitian Universitas Jambi Seri Sains, 17(1), 7683. [In Bahasa Indonesia]. 